\title{
Analisa Steganografi untuk Citra Bewarna (RGB) Menggunakan Metode Less Significant Bit (LSB)
}

\author{
Raihan Islamadina $^{1 *}$, Baihaqi $^{2}$, dan Mauzar sulistriadi ${ }^{3}$ \\ 1,2,3 Program Studi Teknik Informatika \\ Fakultas Teknik Universitas Serambi Mekkah \\ Jl. T. Imum Lueng Bata Batoh - Banda Aceh \\ e-mail: raihan.islamadina@ serambimekkah.ac.id
}

\begin{abstract}
Abstrak - Perkembangan teknologi informasi dan komunikasi yang sangat pesat memungkinkan orang untuk saling bertukar informasi/data melalui jaringan Internet. Pemanfaatkan teknologi dan informasi yang berkembang rentan terhadap kejahatan. Maka dari itu sejalan dengan perkembangan media internet ini juga harus diimbangi dengan teknik pengamanan untuk melindungi informasi/data. Salah satu teknik pengamanan informasi adalah steganografi yang merupakan seni atau praktik menyembunyikan pesan, citra, atau file kedalam pesan, citra atau file yang lain dengan maksud agar pihak yang tidak berhak memiliki pesan tersebut tidak menyadari keberadaan dari pesan yang disembunyikan. LSB (Least Significant Bit) merupakan salah satu teknik atau algoritma pada steganografi yang digunakan dalam penelitian ini. Teknik LSB adalah teknik tiap bit dari pesan yang menggantikan bit terendah dari piksel warna pada citra digital. Proses penggantian bit terus dilakukan secara berulang pada tiap urutan piksel warna pada citra digital. Sehingga, informasi yang berharga tidak dapat diakses oleh pihak yang tidak bertanggung jawab dan terkesan tidak bernilai.
\end{abstract}

Kata kunci: citra digital, steganografi, LSB (Least Significant Bit)

\section{Pendahuluan}

Perkembangan teknologi informasi dan komunikasi yang sangat pesat memungkinkan untuk saling bertukar informasi/data melalui jaringan Internet. Seiring dengan perkembangan teknologi, kejahatan yang memanfaatkan teknologi dan informasi juga turut berkembang. Banyak cara yang dicoba untuk mengakses informasi/data yang bukan haknya. Maka dari itu, sejalan dengan perkembangan media internet juga harus di imbangi dengan teknik pengamanan untuk melindungi informasi/data dari pihak yang tidak berhak.

Salah satu teknik pengamanan informasi adalah steganografi yang merupakan seni atau praktik menyembunyikan pesan, citra, atau file kedalam pesan, citra atau file yang lain. Steganografi meliputi penyembunyian informasi dalam file komputer. Dalam steganografi digital, komunikasi elektronik dapat mencakup steganografi coding dalam lapisan transport, seperti file dokumen, file gambar, program atau protokol. Steganografi menggunakan teknik dari algoritma LSB (Least Significant Bit). Teknik LSB adalah teknik dimana tiap bit dari pesan akan menggantikan bit terendah dari piksel warna pada citra digital. Proses penggantian bit terus dilakukan secara berulang pada tiap urutan piksel warna pada citra digital.

Penerapan steganografi pada komunikasi publik, dimana pesan atau informasi mengalir pada jaringan yang digunakan oleh banyak orang ke penerima yang menyebabkan sulitnya menjaga atau mengamankan informasi dari pihak - pihak luar seperti penyadap atau peretas selama informasi tersebut mengalir ke penerima. Informasi ditanamkan pada media lain sehingga seolah-olah informasi yang dikomunikasikan adalah media tersebut yang mana media penampung tidak lebih berharga dari informasi yang ditanamkan pada media tersebut. Sehingga, dengan adanya penerapan steganografi dapat mengatasi masalah keamanan informasi yang berharga tidak dapat diakses oleh pihak yang tidak bertanggung jawab dan terkesan tidak bernilai.

\section{Tinjauan Pustaka}

\subsection{Citra Digital}

Citra adalah suatu representasi (gambaran), kemiripan, atau imitasi dari suatu objek. Citra terbagi 2 yaitu ada citra yang bersifat analog dan ada citra yang bersifat digital. Citra analog adalah citra yang bersifat kontinu seperti gambar pada monitor televisi, foto sinar X, hasil CT Scan dan lain-lain. Sedangkan pada citra digital adalah citra yang dapat diolah oleh komputer [1]. Citra digital juga direpresentasikan dalam kata, gambar dan grafis yang mendiskripsikan dalam bentuk numeris melalui piranti komputer. Pengolahan citra digital menunjuk pada pemrosesan gambar 2 dimensi menggunakan komputer. Dalam konteks yang lebih luas, pengolahan citra digital mengacu pada pemrosesan setiap data 2 dimensi. Citra digital merupakan sebuah larik (array) yang direpresentasikan dengan deretan bit tertentu [2]. Citra digital aada tiga jenis, yaitu citra biner yang terdiri dari dua warna yaitu hitam dan putih, citra grayscale (skala keabuan) merupakan citra 2 bit mewakili 4 warna, citra 3 bit mewakili 8 warna, dan seterusnya, dan citra warna (true color) yaitu piksel pada citra warna mewakili warna yang merupakan kombinasi dari tiga warna dasar $(\mathrm{RGB}=$ Red Green 
Blue). Setiap warna dasar menggunakan penyimpanan 8 bit $=1$ byte, yang berarti setiap warna mempunyai gradasi sebanyak 255 warna. Berarti setiap piksel mempunyai kombinasi warna sebanyak $28 \times 28 \times 28=224=16$ juta warna lebih. Itulah sebabnya format ini dinamakan true color karena mempunyai jumlah warna yang cukup besar sehingga bisa dikatakan hampir mencakup semua warna di alam [1].

\subsection{Steganografi}

Istilah steganografi berasal dari bahasa Yunani, yaitu steganos yang berarti penyamaran atau penyembunyian dan graphein yang berarti tulisan. Jadi, steganografi bisa diartikan sebagai seni menyembunyikan pesan dalam data lain tanpa mengubah data yang ditumpanginya tersebut sehingga data yang ditumpanginya sebelum dan setelah proses penyembunyian hampir terlihat sama [3]. Data yang disembunyikan terbuka, selalu terihat, tetapi tidak terdeteksi bahwa adanya pesan rahasia. Deskripsi lain yang popular untuk steganografi adalah Hidden in Plain Sight yang artinya tersembunyi didepan mata.

\subsection{LSB (Least Significant Bit)}

LSB (Least significant bit) adalah bagian dari barisan data biner (basis dua) yang mempunyai nilai paling kecil. Letaknya adalah paling kanan dari barisan bit. Metode LSB digunakan dalam teknik steganographi dikarenakan tergolong mudah dalam penerapannya. Dasar dari metode ini adalah bilangan berbasiskan biner atau angka 0 dan 1 . Metode ini berhubungan erat dengan ukuran 1 bit dan ukuran 1 byte. 1 byte data dapat dikatakan terdiri dari 8 bit data, dengan bit pada posisi paling kanan yang disebut dengan bit pada posisi LSB. Teknik steganografi dengan menggunakan metode LSB adalah teknik dimana kita mengganti bit pada posisi LSB pada data dengan bit yang dimiliki oleh data yang akan disembunyikan. Karena bit yang diganti hanyalah bit yang paling akhir, maka meskipun data telah berubah, kita tetap tidak akan bisa mengenalinya, karena media stego yang dihasilkan hampir sama persis dengan media sebelum disisipi oleh data yang ingin disembunyikan.

\section{Metode Penelitian}

3.1 Sampel Citra Digital

Penelitian ini menggunakan sampel citra digital berwarna (RGB) yang di ambil dari database USCSIPI [4]. Sampel citra berwarna (RGB) terdapat pada table 1 .

Tabel 1. Sampel Citra Digital Berwarna(RGB)

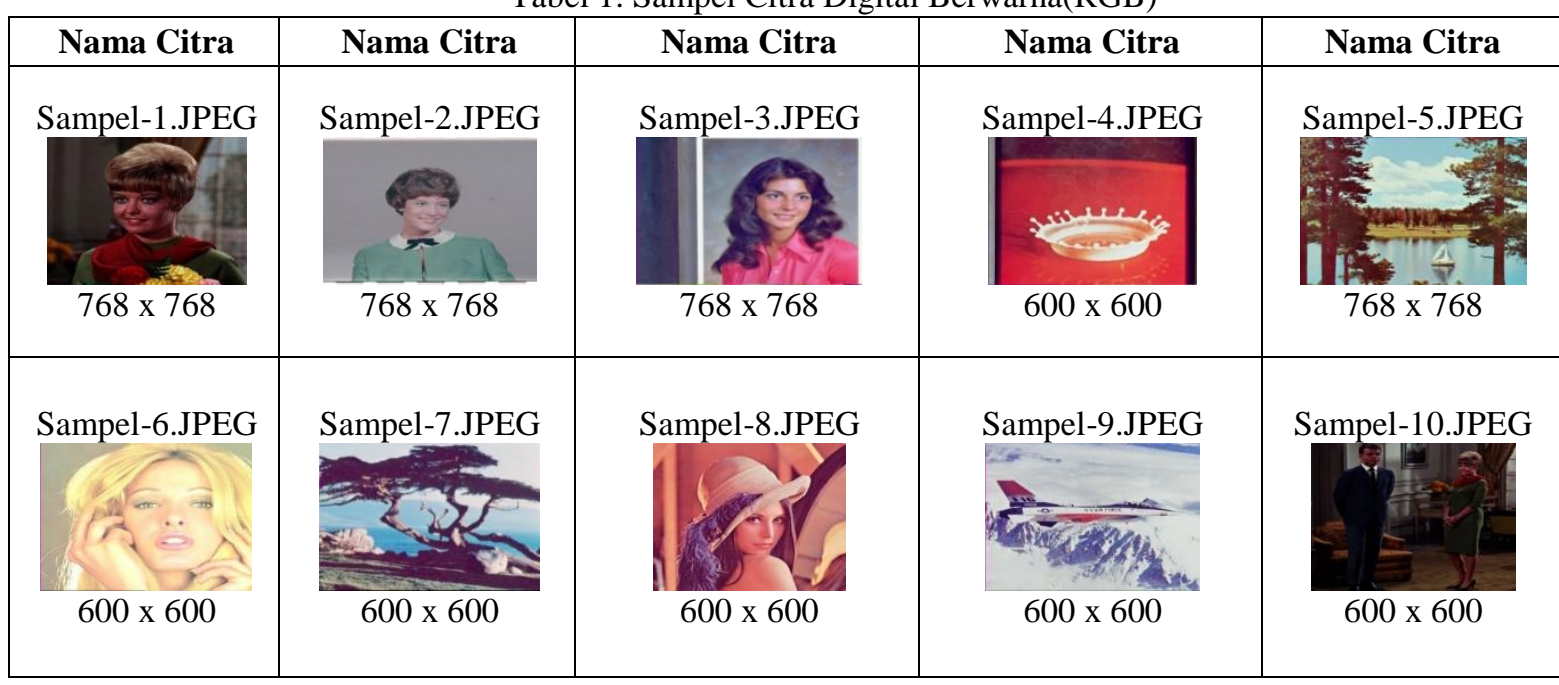

Dari sepuluh citra berwarna (RGB) diatas memiliki resolusi yang berbeda. Untuk citra sampel1, sampel-2, sampel-3, sampel-4 dan citra sampel-5 memiliki resolusi 768 × 768 dan citra sampel-6, sampel-7, sampel-8, sampel-9, dan citra sampel-10 memiliki resolusi 600 x 600. Penggunaan citra RGB dengan dua resolusi yang berbeda dikarenakan resolusi tersebut sangat tepat untuk aplikasi steganografi dan ukuran file citra dengan resolusi tersebut tidak terlalu besar sehingga citra yang digunakan bisa diinput diaplikasi steganografi.

Sedangkan gambar 2 menjelaskan diagram alir dari proses ekstraksi citra. Proses dimulai dari input image steganografi untuk pengenalan apakah image tersebut terdeteksi atau tidak. Jika image tidak terdeteksi maka akan kembali ke inputan image steganografi dan jika image terdeteksi maka akan dilanjutkan ke proses ekstraksi. Setelah proses ekstraksi terjadilah proses pengambilan bit dari image. Kemudian proses pengambilan byte dari image dan proses susun byte menjadi teks, sehingga menampilkan output tampilan teks yang selanjutnya teks tersebut akan disimpan 


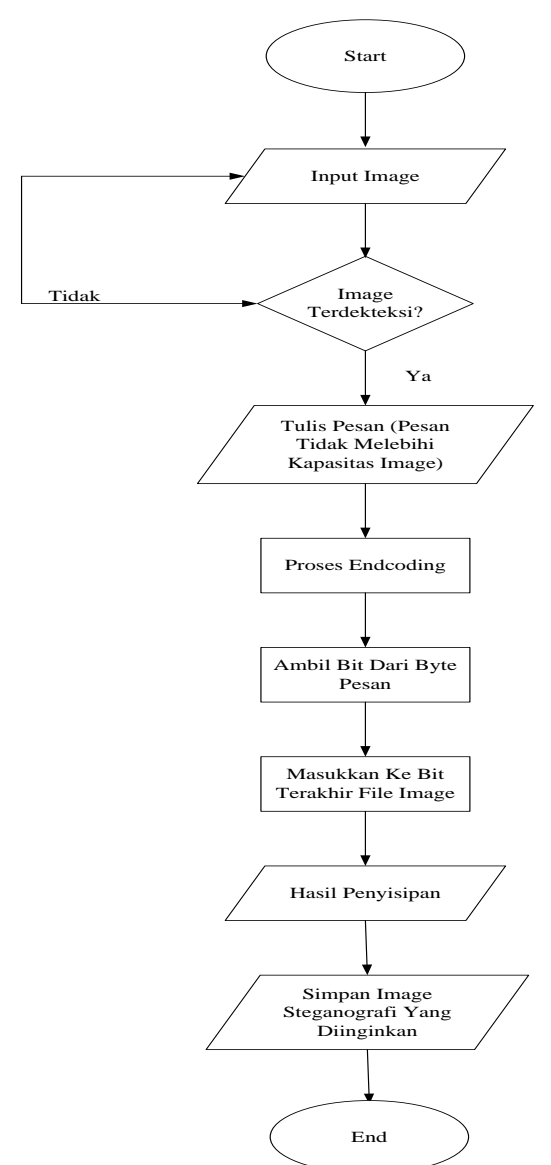

Gambar 1. Proses Penyisipan Pesan

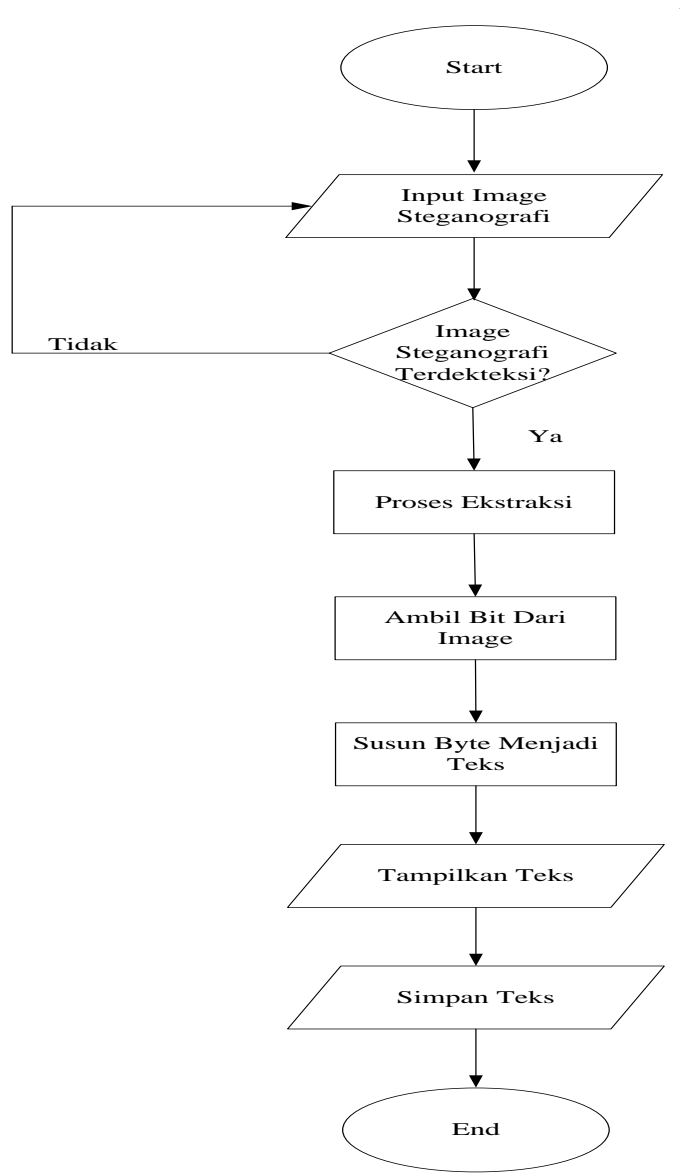

Gambar 2. Proses Ekstraksi Citra

\subsection{Proses Steganografi dengan Metode LSB}

Proses penyisipan pesan atau menyembunyikan pesan terdapat dalam gambar 3.3 dan gambar 3.4. Gambar 3.3 berupa sebuah pesan file docx yang akan disembunyikan ke dalam sebuah file gambar berformat JPEG dengan ukuran maksimum file adalah 5MB. Sedangkan Gambar 3 adalah file gambar yang akan dijadikan tempat penyisipan pesan atau file. Jenis gambar yang digunakan untuk menyembunyikan file rahasia adalah berformat JPEG dengan kapasitas diatas $606 \mathrm{~KB}$.

Teknik steganografi modifikasi LSB dilakukan dengan memodifikasi bit-bit yang termasuk bit LSB pada setiap byte warna pada sebuah pixel. Bit-bit LSB ini akan dimodifikasi dengan menggantikan setiap LSB yang ada dengan bit-bit informasi lain yang ingin disembunyikan. Setelah semua bit informasi lain menggantikan bit LSB didalam file tersebut, maka informasi telah berhasil disembunyikan seperti pada gambar 4 berupa file image yang sudah berhasil disisipkan file rahasia. Secara kesat mata tidak melihat perubahan dari file image asilnya, akan tetapi file image yang sudah disisipkan mengalami perubahan dari kualitas gambar serta ukuran file image yang semakin besar. Disini, ukuran file image awal adalah $606 \mathrm{~KB}$, file rahasia yang akan disembunyikan 53.7 KB dan hasil file penyisipan adalah 1.02 MB. 


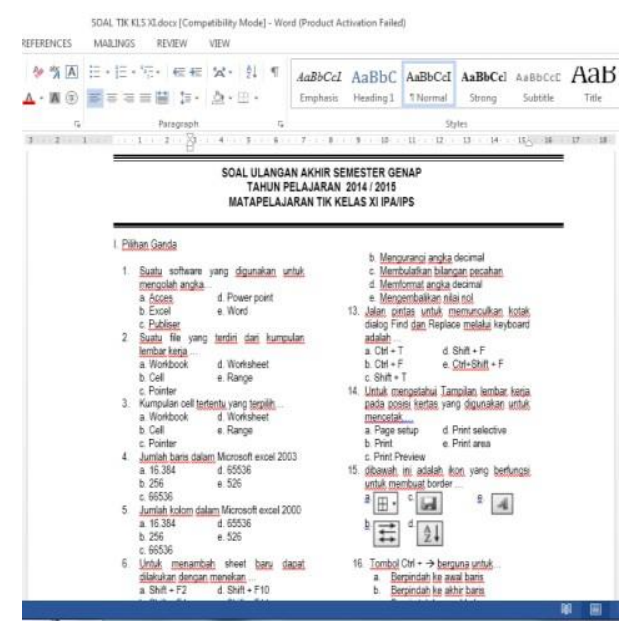

Gambar 3. File docx awal sebelum disisipkan

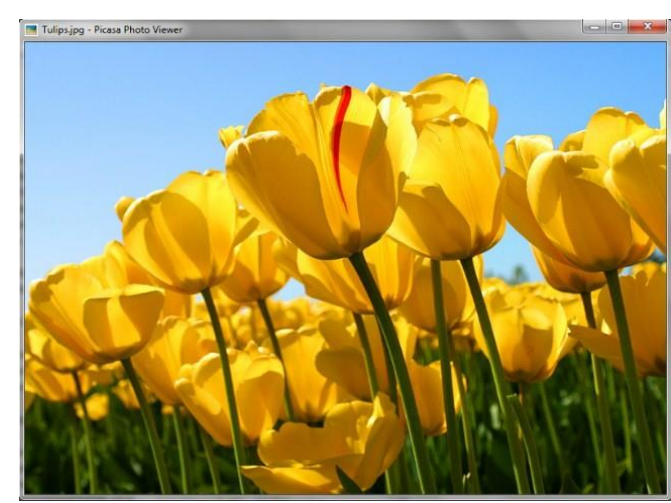

Gambar 4. File Gambar yang telah disisipkan file doxc

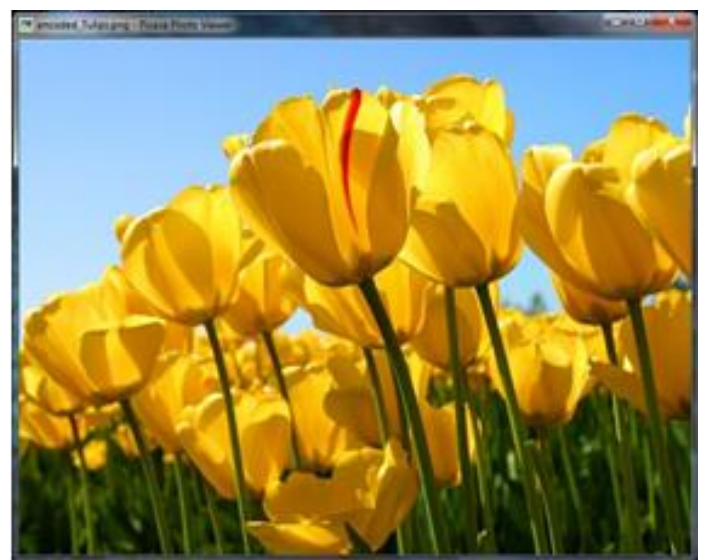

Gambar 5. File gambar yang akan diekstraksi

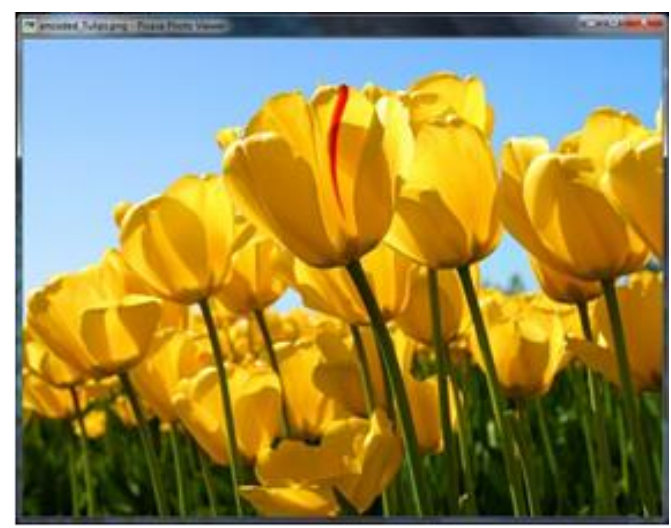

Gambar 6. File gambar yang akan menjadi cover

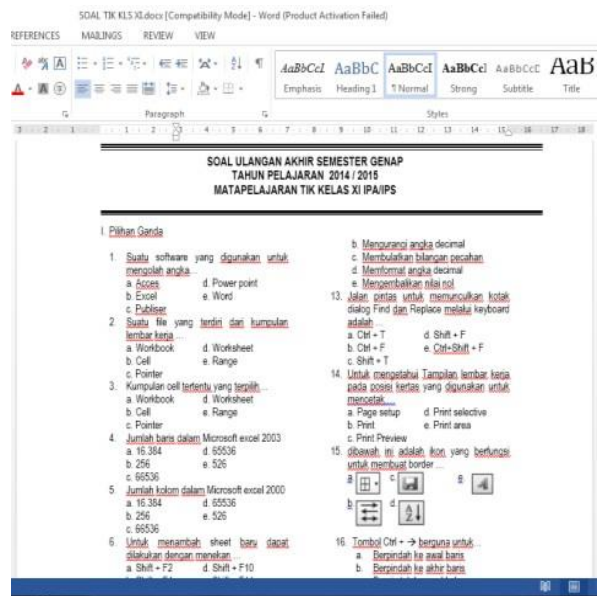

Gambar 7. Hasil ekstraksi file dari gambar yang telah disisipkan file

Sedangkan proses ekstraksi adalah proses pengembalian pesan atau file yang sudah disembunyikan ke dalam gambar. Ekstraksi digunakan untuk melakukan pengekstrasan pesan file terhadap gambar yang sudah disisipkan sebelumnya. Pada saat proses ekstraksi, bit-bit LSB yang sekarang ada diambil satu persatu kemudian disatukan kembali menjadi sebuah informasi yang utuh seperti semula. Penentuan bit-bit LSB dilakukan secara berurutan. Mulai dari byte awal sampai byte terakhir sesuai panjang dari data rahasia yang disembunyikan. LSB hanya mengubah nilai byte satu lebih tinggi atau satu lebih rendah dari nilai sebelumnya tidak berpengaruh terhadap persepsi visual/auditori. 


\section{Hasil dan Pembahasan}

\subsection{Proses Enkripsi Citra Warna (RGB)}

Proses enkripsi citra warna (RGB) dijelaskan dalam gambar-gambar berikut: Gambar 8 merupakan langkah awal untuk proses enkripsi dengan cara load cover image yang akan disisipkan pesan. Dilanjutkan dengan menulis pesan yang akan disisipkan pada cover image seperti gambar 9. Setelah menulis pesan kemudian klik perintah LSB Method, 3-bit Encoder, 101-bit Encoder dan 110-bit Encoder. Maka akan keluar hasil embedded dari cover image asal seperti pada gambar 10. Disini, terdapat hasil embedded dari cover image asal yang mana citra hasil embedded terlihat sama dengan cover image asal. Selanjutnya pada gambar 11 menampilkan hasil dari enkripsi pesan (teks) yang telah berhasil dengan cara klik perintah text encrypt. Maka hasil embedded otomatis terganti dengan hasil embedded yang mengukur tingkat keabu-abuan dan juga setelah melakukan proses enkripsi maka size image cover asal berubah menjadi lebih besar dari pada size sebelumnya. Adapun hasil proses enkripsi dari awal hingga akhir terdapat pada tabel 2 .
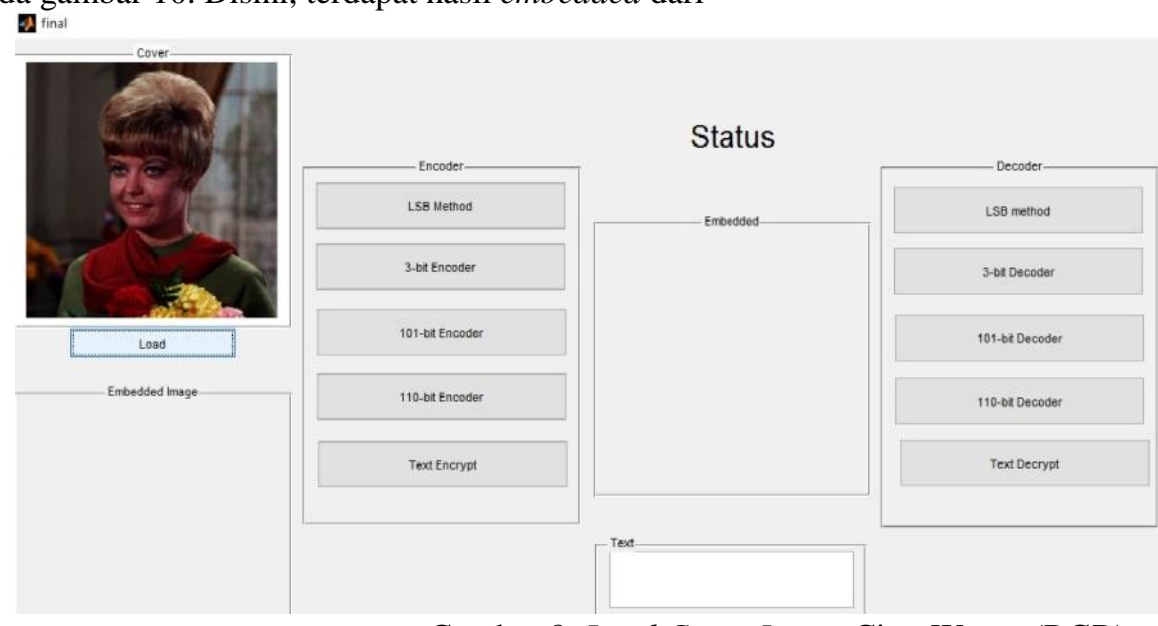

Status

Gambar 8. Load Cover Image Citra Warna (RGB)

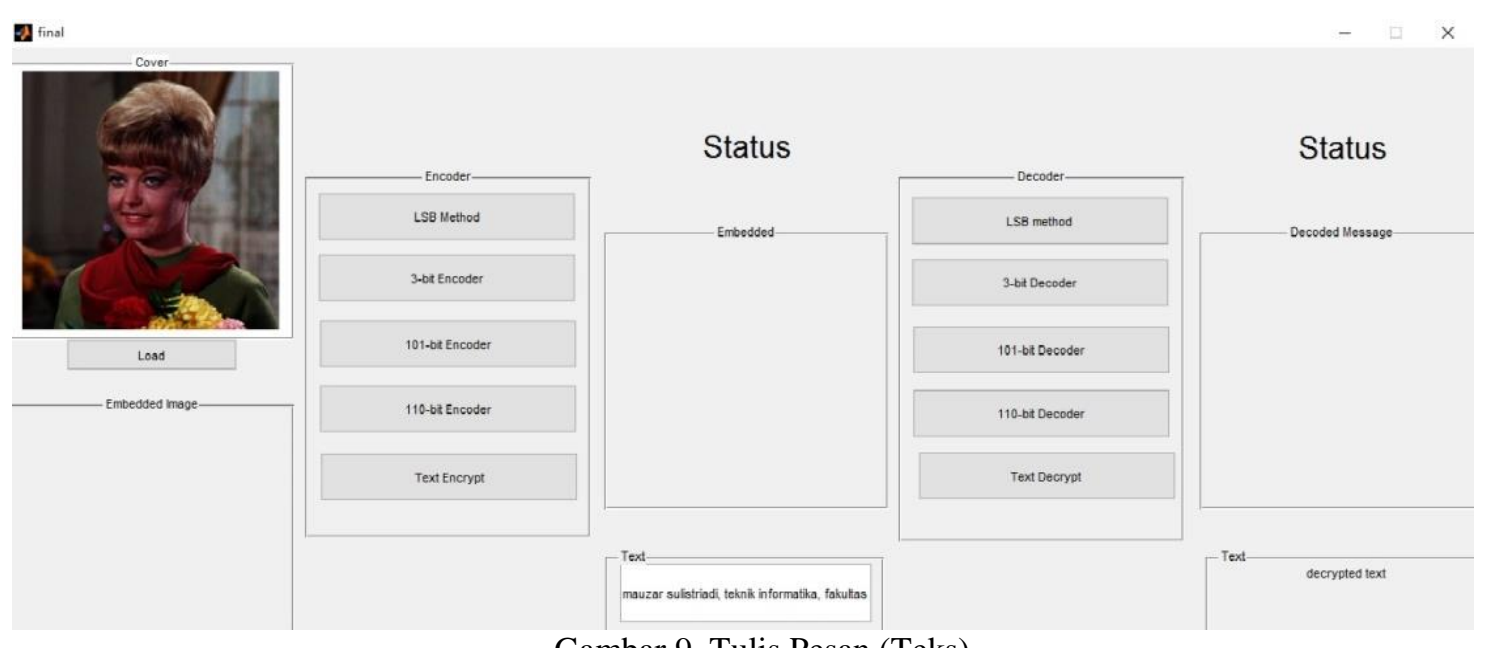

Gambar 9. Tulis Pesan (Teks) 


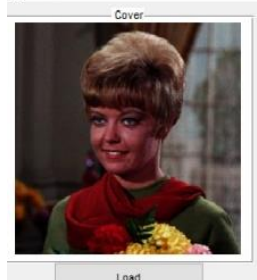

Loso

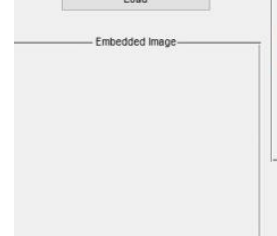

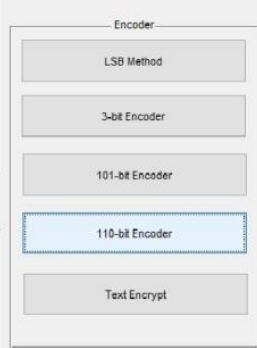

Gambar 10. Hasil Embedded dari cover image asal

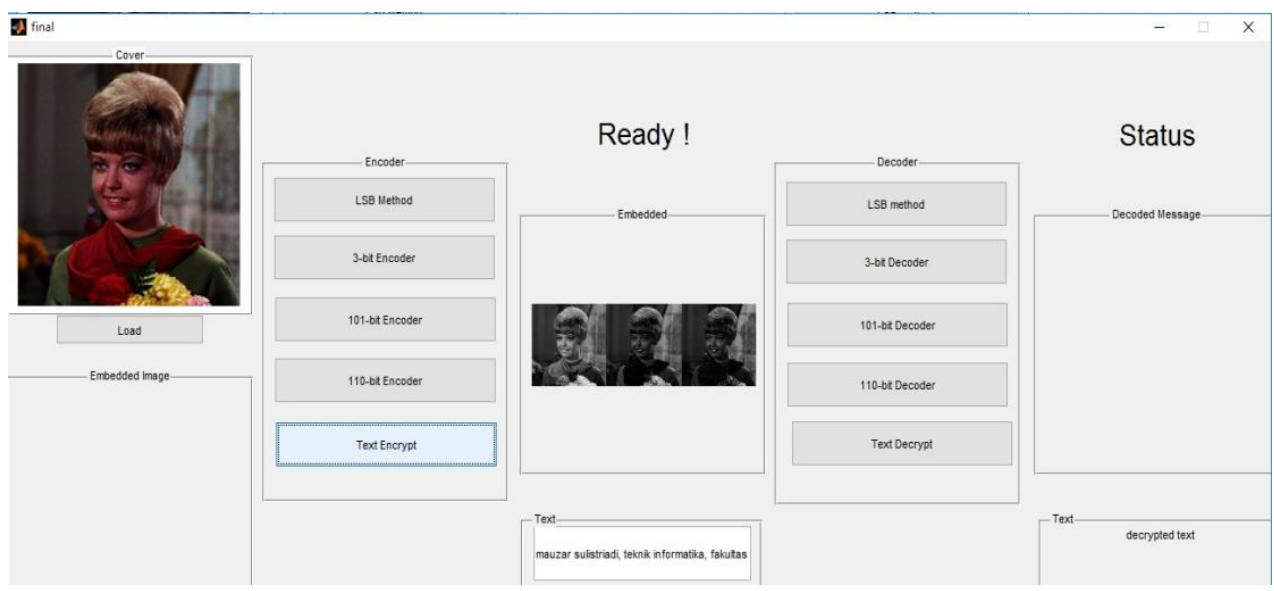

Gambar 11. Tampilan Hasil Enkripsi Pesan Teks

Tabel 2. Hasil Proses Enkripsi Citra Warna (RGB)

\begin{tabular}{|c|c|c|c|}
\hline Citra Asal & Embedded & $\begin{array}{c}\text { Embedded Tingkat } \\
\text { Keabu-abuan }\end{array}$ & Teks Yang Disisipkan (Enkripsi) \\
\hline & & & \\
\hline
\end{tabular}

Dari tabel terdapat citra asal, embedded, embedded tingkat keabu-abuan dan teks yang disisipkan (enkripsi). Citra asal memiliki resolusi 768 x 768 dan size 49,1 KB, setelah dienkripsi pesan (teks) maka hasil embedded mempunyai resolusi yang tetap sama dengan citra asal yaitu 768 x 768, tetapi hasil embedded mempunyai size yang lebih besar dari citra asal yaitu 49,1 KB menjadi 49,6 KB. Hasil embedded dan embedded tingkat keabu-abuan terjadi karena adanya proses LSB Method, 3-bit Encoder, 101-bit Encoder dan 110-bit Encoder. Dan untuk hasil embedded tingkat keabu-abuan pada citra warna (RGB) memiliki tingkat keabu-abuan yang berbeda-beda.

\subsection{Proses Deskripsi Citra Warna (RGB)}

Proses deskripsi citra warna (RGB) dimulai dari gambar 12 yaitu menginput image hasil embedded. Selanjutnya pada gambar 13 merupakan kelanjutan inputan image embedded dimana image embedded akan tampil setelah proses load. Kemudian pada gambar 14 merupakan hasil dari deskripsi pesan (teks) dan pesan tersebut akan tampil otomatis setelah melakukan proses deskripsi dengan cara mengeklik text decrypt. Gambar 15 merupakan hasil deskripsi code image, dimana hasil deskripsi code image tersebut akan tampil setelah mengeklik LSB Method 
pada decoder. Hasil proses deskripsi dari awal hingga

akhir dapat terdapat pada Tabel 4.2.
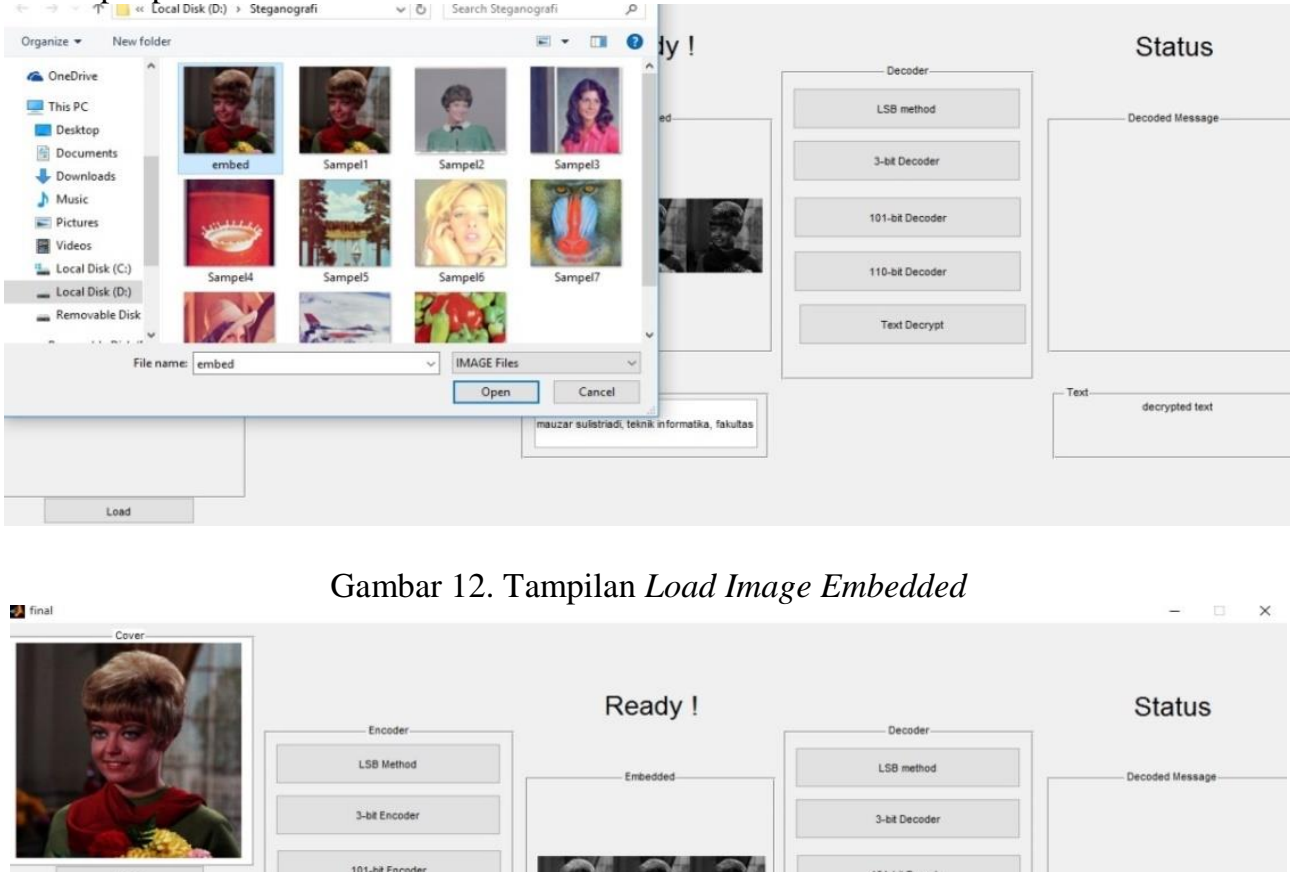

Gambar 12. Tampilan Load Image Embedded
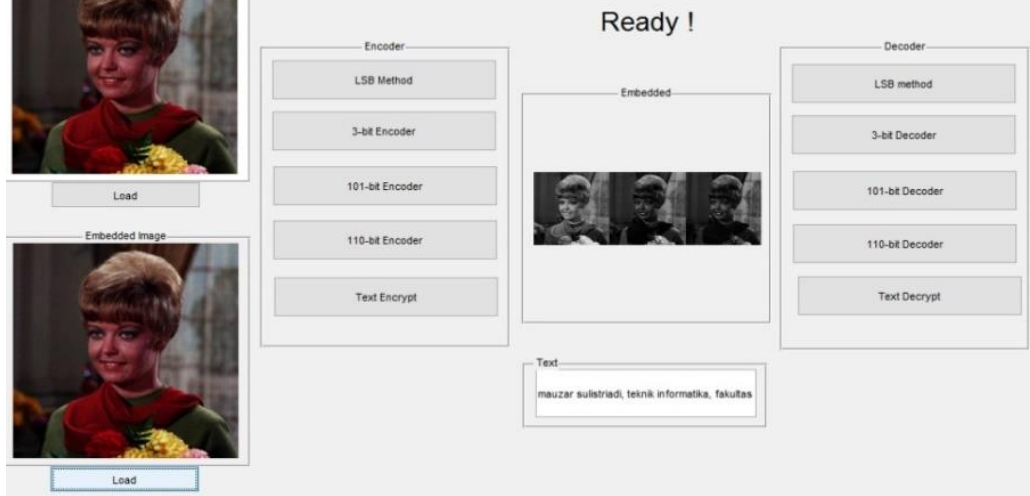

Status

Gambar 13. Tampilan Setelah Load Image Embedded

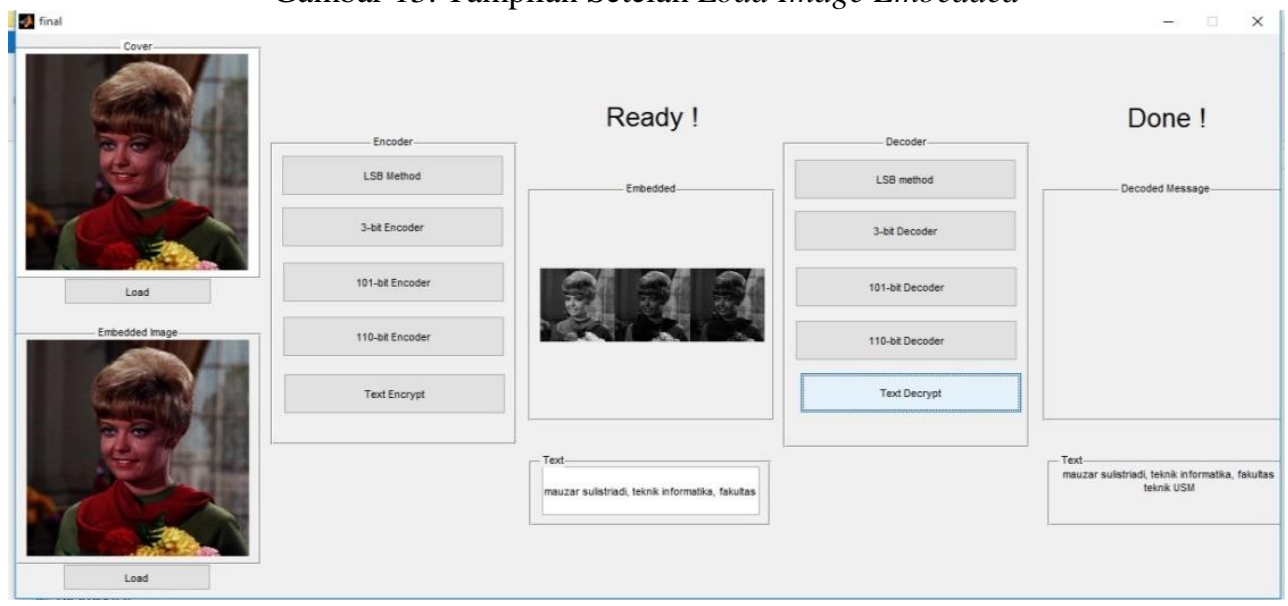

Gambar 14. Tampilan Setelah Pesan (Teks) Di Deskripsi 
国 final

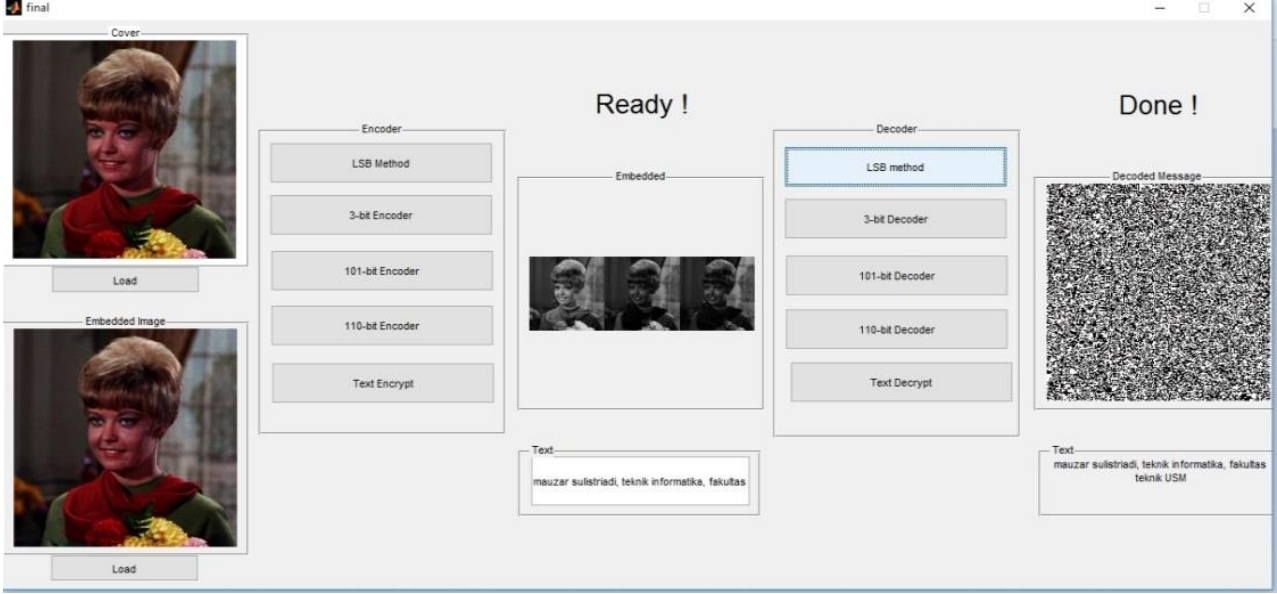

Gambar 15. Tampilan Hasil Deskripsi Code Image

Tabel 3. Hasil Proses Deskripsi Citra Warna (RGB)

\begin{tabular}{|c|c|c|c|}
\hline $\begin{array}{c}\text { Citra } \\
\text { Embedded }\end{array}$ & Deskrip Code Image & Embedded Tingkat Keabu-abuan & $\begin{array}{c}\text { Hasil Teks Yang } \\
\text { Telah Disisipkan } \\
\text { (Deskripsi) }\end{array}$ \\
\hline & & & $\begin{array}{c}\text { mauzar sulistriadi, } \\
\text { teknik informatika, } \\
\text { fakultas teknik USM }\end{array}$ \\
\hline
\end{tabular}

Hasil deskrispi ini terdapat citra embedded, deskrip code image, embedded tingkat keabu-abuan dan hasil teks yang telah disipkan (deskripsi). Hasil deskripsi code image merupakan hasil dari proses metode LSB dimana bit terakhir pada image embedded ini diganti dengan bit-bit pada teks. Untuk hasil deskripsi code image berbeda dengan citra image embedded dan hasil teks yang telah disisipkan (deskripsi) sama dengan teks yang disisipkan (enkripsi). Adapun hasil untuk semua sampel citra warna (RGB) terdapat pada tabel 3.

Tabel 4 merupakan hasil keseluruhan sampel dari proses enkripsi dan deskripsi pada steganografi untuk citra warna (RGB), dimana pada tabel ini terdapat citra asal, embedded, embedded tingkat keabu-abuan, deskripsi code image, size image setelah di enkripsi dan teks yang disisipkan (enkripsi/deskripsi).

Tabel 4. Hasil Semua Sampel Enkripsi dan Deskripsi Steganografi

\begin{tabular}{|c|c|c|c|c|c|}
\hline Citra Asal & Embedded & $\begin{array}{c}\text { Embedded Tingkat } \\
\text { Keabu-abuan }\end{array}$ & $\begin{array}{c}\text { Deskripi } \\
\text { Code Image }\end{array}$ & $\begin{array}{l}\text { Size } \text { Setelah } \\
\text { Di Enkripsi }\end{array}$ & $\begin{array}{l}\text { Teks yang disisipkan } \\
\text { (Deskripsi/Enkripsi) }\end{array}$ \\
\hline Sampel_ & & 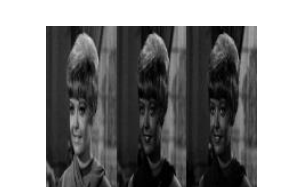 & & $49,6 \mathrm{~KB}$ & $\begin{array}{l}\text { mauzar sulistriadi, } \\
\text { teknik informatika, } \\
\text { fakultas teknik USM }\end{array}$ \\
\hline
\end{tabular}


E-ISSN 2621-3052

\begin{tabular}{|l|l|l|l|l|l|}
\hline Sampel_2 & (n) & Universitas Serambi \\
Mekkah
\end{tabular}

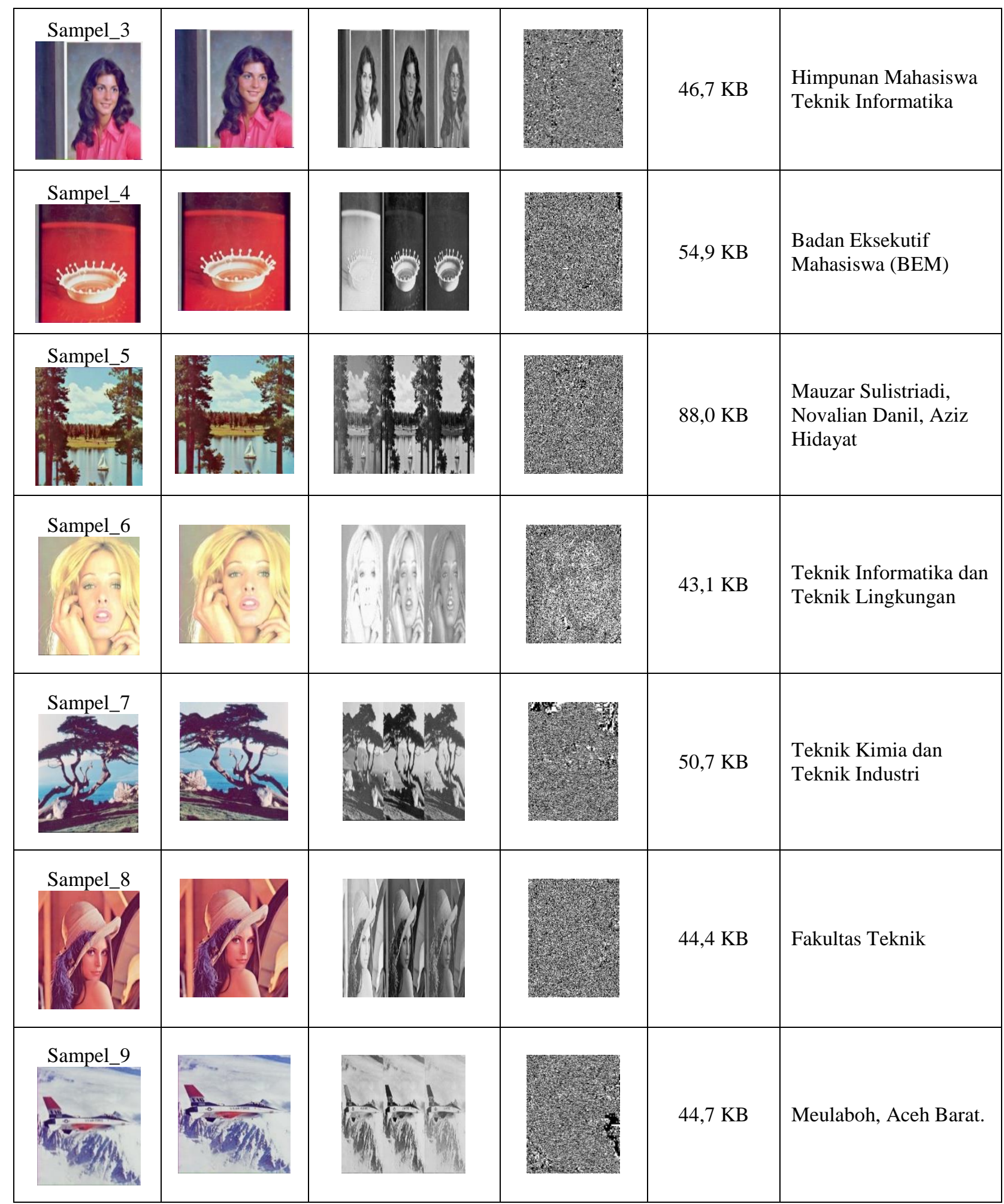




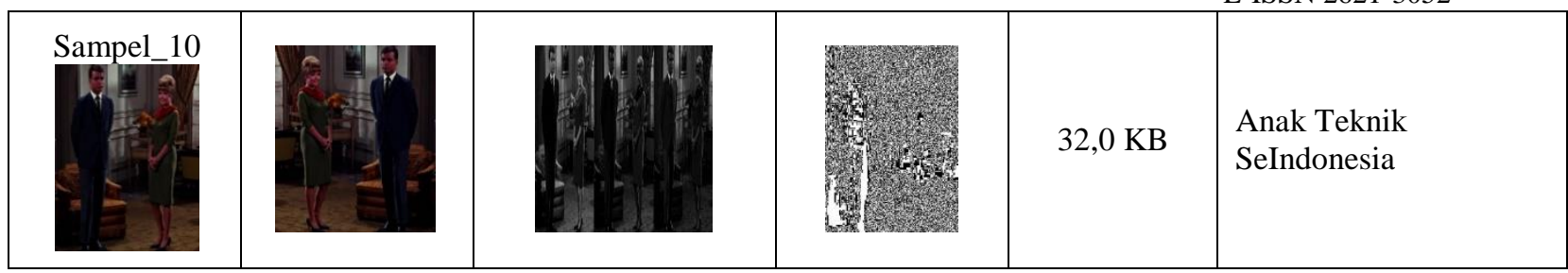

\section{Kesimpulan}

Hasil simulasi steganografi untuk citra digital berwarna (RGB) menggunakan bahasa pemograman berbasis Matlab yang dilakukan pada sepuluh sampel citra warna (RGB) menunjukkan hasil embedded tingkat keabu-abuan yang berbeda-beda. Dengan adanya perbedaan tingkat keabu-abuan tersebut menjadikan informasi yang berharga tidak dapat diakses oleh pihak yang tidak bertanggung jawab dan terkesan tidak bernilai.

\section{Daftar Pustaka}

[1] Sutoyo, T, dkk. 2009. Teori Pengelohan Citra Digital hal $9-27$. Yogyakarta : Penerbit Andi

[2] Putra, Darma. 2010. Pengolahan Citra Digital. Yogyakarta : Penerbit Andi

[3] Ariyus, D. 2009. Keamanan Multimedia. Yogyakarta: Andi.

[4] Online. http ://sipi.usc.edu/database-

[5] Jogiyanto. 2010. Analisis dan Desain Sistem Informasi. Yogyakarta: CVAndi Offset, Edisi IV.

[6] Wijaya, Marvin Ch. \& Agus Prijono. 2007. Pengolahan Citra Digital Menggunakan Matlab. Jakarta: Informatika.

[7] Zulfan dan Baihaqi. "Pemanfaatan Konten Multimedia Animasi Dua Dimensi sebagai Media Pelestarian Alat Musik Etnik Aceh." Jurnal Nasional Komputasi dan Teknologi Informasi (JNKTI) 1, no. 2 (2018). 